\title{
ANÁLISE FENOTÍPICA E GENOTÍPICA DE BACTÉRIAS ISOLADAS DO SOLO DA FLORESTA NACIONAL DOS TAPAJÓS, PARÁ, BRASIL, SOB EFEITO DE ESTRESSE HÍDRICO
}

\author{
BATISTA, Selma Baia \\ Centro de Ciências Biológicas e da Saúde (CCBS) Universidade Federal do Mato Grosso. Av. Fernando \\ Correia da Costa. Bairro Boa Esperança, Cuiabá-MT. CEP 78060-900. Brasil. Tel. (65) 63615-8970. \\ E-mail: selbbat@yahoo.com.br \\ HARGREAVES, Paulo Iiboshi; MENDONÇA-HAGLER, Leda Cristina \\ Instituto de Microbiologia Prof. Paulo de Góes (IMPPG) UFRJ; Laboratório de Ecologia Microbiana e \\ Taxonomia; Centro de Ciências da Saúde (CCS), Bloco I, sala 44, Ilha do Fundão-RJ. CEP 21941-590. \\ Brasil. Tel. (21) 2562-6739. \\ SOUSA, Oscarina Viana de \\ Instituto de Ciências do Mar - LABOMAR UFC; Av. da Abolição, 3207 - Meireles - Fortaleza-CE. CEP \\ 60165-081. Tel. (85) 3366-7000
}

\section{RESUMO}

Os solos da Floresta Nacional dos Tapajós são classificados como argilosos e podzólicos, possuem acidez elevada, altos teores de alumínio e são pobres em nutrientes. Visando avaliar o impacto das secas nafloresta, foi desenvolvido o projeto "Dry Forest". Este projeto inclui as parcelas Floresta Primária (FP, controle) e Floresta Seca (FS, com exclusão de chuvas). O presente estudo avaliou o efeito do estresse hídrico sobre a microbiota do solo nessas parcelas. Foram analisadas 12 amostras de solo por parcela quanto às populações microbianas, incluindo organismos celulolíticos, proteolíticos e solubilizadores de fosfato. Foi observada uma redução nas contagens microbianas no solo sob estresse hídrico, podendo atingir duas ordens de grandeza, sendo mais expressiva para os microrganismos celulolíticos. Das 286 culturas bacterianas isoladas, os bastonetes Gram positivos representaram 47\% (FP) e 62\% (FS) destes isolados. Os gêneros prevalentes foram Bacillus, Corynebacterium, Listeria e Micrococcus. Foi encontrada significativa diversidade genotípica entre as estirpes isoladas (FP e FS) nos perfis de BOX-PCR. Os resultados permitem concluir que a exclusão de chuvas na parcela seca pode provocar redução nas populações microbianas. No entanto, a diversidade encontrada, em nível de gênero, foi pouco influenciada. A elevada diversidade bacteriana detectada ao nível de espécie/subespécie sugere uma resiliência dos solos de ambas as parcelas ao estresse ambiental.

Palavras-chave: Microbiota do solo; Atividade enzimática do solo; Estresse hídrico; BOX-PCR; Floresta Amazônica.

\begin{abstract}
Soils from the National Forest of Tapajos are nutrient-poor, acidic, podzolic clay types, with highaluminum content. The Dry Forest Project was developed to assess the impact of drought on a tropical forest. This project includes plots of Primary Forest (FP, control) and Dry Forest (FS, with exclusion of rain). This study assessed the effect of dryness on the microbial populations of soils collected in these plots. Twelve soil samples were analyzed for counts of total bacteria, fungi, and cellulolytic, proteolytic and phosphate solubilizer populations. Adecrease of microbial counts was detected at the dry forest plot in comparison with the control, being more significant (two orders of magnitude) for cellulolytic populations. The majority of 286 isolated cultures were Gram-positive bacilli (47\% for FP and 62\% for FS) and the prevalent genera were Bacillus, Corynebacterium, Listeria and Micrococcuss. Box-PCR profiles of the bacteria from both plots showed high genetic diversity. The exclusion
\end{abstract}


of rain can produce a negative effect on the microbial populations of tropical forest soil. The diversity, at the genus level, does not appear to be affected by drought, and the high diversity found for bacteria at the species/ subspecies level at both sites suggested a resilience of the soil microbiota to this environmental stress.

KeYwords: Soil microbes; Soil enzymatic activities; Stress by drought; BOX-PCR, Amazon Forest.

\section{INTRODUÇÃo}

AFloresta Amazônica sofre eventos anuais de seca sazonal no período de Junho a Novembro, causados por uma perda de água para a atmosfera através de evapotranspiração. A absorção da umidade do solo é o fator determinante para manter a floresta verde e fisiologicamente ativa durante esse período (KALIF et al., 2000). No caso de estiagens prolongadas, frequentes devido ao fenômeno climático El Niño, a umidade nas camadas mais profundas do solo também é perdida para a atmosfera. Sob essas condições, a floresta sofre alterações que a tornam mais seca e suscetível ao fogo (NEPSTAD et al., 1995). Para prever o efeito de seca prolongada, é importante avaliar a resistência da Floresta Amazônica e planejar melhor a sua conservação. Nesse contexto foi desenvolvido o Projeto "Dry Forest", por meio de uma abordagem experimental que avaliou a resposta da vegetação a uma estiagem produzida artificialmente através da exclusão de chuvas, em uma área da Floresta Nacional dos Tapajós, em Santarém, no Estado do Pará (NEPSTAD et al., 2000). Os solos dessa floresta são argilosos e podzólicos, apresentam coloração vermelha ou amarela; são pobres em nutrientes, possuem acidez elevada e altos teores de alumínio (CERRI et al., 1985). Neles, a riqueza nutricional normalmente está concentrada na camada superficial, devido ao depósito de resíduos vegetais na serrapilheira, além dos efeitos das raízes. Assim, a matéria orgânica é incorporada pelos microrganismos. Havendo disponibilidade de água, a decomposição parcial realizada pelos mesmos vai dar origem à matéria orgânica que reterá nutrientes, que serão liberados lentamente para os colonizadores do solo (BORNEMAN e TRIPLETI, 1997).

A diversidade microbiana do solo da Floresta Amazônica é complexa e pouco estudada. Borneman e Tripleti (1997) realizaram uma análise desse solo por meio do método de RISA, e encontraram bactérias dos grupos Plactomyces, Clostridium, Gram positivos com alto teor de Guanina/Citosina, Cytophaga-Flexibacter-Bacteriodes, Fibrobacterium e da sub-classe Proteobactéria.

Os microrganismos são reconhecidos por sua habilidade em promover transformações bioquímicas dos nutrientes e por sua importância em disponibilizar elementos nutritivos às plantas (NAHAS, 2002). Grupos microbianos podem ser utilizados como indicadores na estimativa dessas transformações por meio da biomassa e de suas atividades enzimáticas, como, por exemplo, celulase, protease e fosfatase, dentre outras (ARIAS et al., 2005). Essas atividades são influenciadas pela variação sazonal, aeração, umidade, vegetação, microbiota, temperatura e tipo de solo (KISS et al., 1975; NAHAS, 2002). As enzimas acumuladas no solo são primariamente provenientes de células microbianas (LADD, 1978); entretanto, um percentual também pode ser originado de resíduos vegetais e animais (BAHLe AGRAWAL, 1972; BRADY, 1989, TABATABAI, 1994). São encontradas no solo na forma livre, excretadas por células vivas (exoenzimas), liberadas por células que se rompem (endoenzimas) e enzimas ligadas a constituintes celulares (KISS et al., 1975). Vários estudos sobre diversidade funcional vêm utilizando métodos baseados em atividades enzimáticas, como celulases, fosfatases e proteases (ZILLI et al., 2003). A degradação microbiana da celulose é um importante processo de decomposição de detritos vegetais (RAI e SRIVASTAVA, 1983; SINSABAUGH e LINKINS, 1988). Afosfatase está ligada aos microrganismos do solo através do ciclo biogeoquímico do fósforo (PAUL e CLARK, 1996), enquanto que a protease é degradada pela maioria dos microrganismos do solo, liberando amônia (ALEF e KLEINER, 1986; MORRA e FREEBORN, 1989).

Técnicas de biologia molecular, como o BOX-PCR, 
possibilitam caracterizar o perfil genotípico de microrganismos cultiváveis (DE BRUIJIN et al., 1992; RADEMAKER et al., 2005), representando ferramentas que complementam os métodos tradicionais de estudo da diversidade microbiana (ZILLI et al., 2003).

O presente estudo teve como objetivo avaliar o efeito do estresse hídrico sobre a diversidade microbiana do solo emduas parcelas da Floresta Nacional dos Tapajós, incluídas no Projeto "Dry Forest".

\section{Metodologia}

As amostras de solo foram coletadas na Floresta Nacional do Tapajós, no município de Santarém, Pará, nas parcelas do experimento montado para o projeto "Dry Forest". No local foi realizada uma simulação do El Niño, onde duas parcelas foram cercadas por trincheiras laterais com profundidade de 1 a 1,7 m. $\mathrm{Na}$ parcela seca (FS), as trincheiras limitaram o abastecimento de água das plantas por raízes laterais e, na úmida (FP), simularam o efeito de borda, evitando esta nova fonte de variação. Para excluir a chuva, 5.660 painéis ( $3 \mathrm{~m} \times 0,5 \mathrm{~m}$ ) foram colocados na parcela seca durante a estação úmida (Janeiro-Maio). Esses painéis são responsáveis por uma redução de 50 a $80 \%$ da água incidente no solo. Essa área da Floresta Nacional dos Tapajós recebe chuvas com média anual de 2000 mm. (CUNHA et al., 2002).

\section{Coleta e processamento das amostras}

As amostras do solo foram coletas em Julho de 2005 e Janeiro de 2006, em profundidade de 0 - 10 $\mathrm{cm}$, em seis pontos aleatórios das duas parcelas: Floresta primária (FP - controle, sem exclusão de chuva) e Floresta Seca (FS - que é a área com exclusão de chuva). De cada área foram coletadas seis amostras compostas a partir de três subamostras, que foram acomodadas em pequenos sacos impermeáveis e esterilizados, e estocadas a $4^{\circ} \mathrm{C}$ até o processamento em laboratório.

\section{Análises Físico-químicas do solo}

As análises físico-químicas determinadas nas amostras de solo foram: percentual de areia, silte e argila, testes expedita de granulometria, nutrientes $(\mathrm{Al}, \mathrm{Ca}+\mathrm{Mg}$, $\mathrm{Ca}, \mathrm{Mg}, \mathrm{P}, \mathrm{K}$ e matéria orgânica) e pH. As análises foram efetuadas seguindo as técnicas recomendadas por Muzilli (1978) e Embrapa (1998) e realizadas nos laboratórios da Empresa Brasileira de Pesquisas Agropecuárias (Embrapa), Setor Solos-Rio de Janeiro.

\section{Enumeração de populações microbianas}

As amostras de solo (10 g) foram suspensas em 90 ml de uma solução contendo $0,1 \%$ pirofosfato de sódio e $0,1 \%$ tween 80 e agitadas 20 minutos. Em seguida foram feitas diluições decimais em $\mathrm{NaCl} 0,85 \%$ e inoculadas (alíquotas de $0,1 \mathrm{ml}$ ) em placas com os diferentes meios de cultivo. Para a quantificação de bactérias heterotróficas foi usado o meio Agar tryptic de soy (TSA, Difcoß) com 0,1 g\% de cicloheximida. As contagens de fungos foram estimadas usando o meio Potato dextrose Agar (PDA, Difco®) cloranfenicol a $0,1 \mathrm{~g} \%$. As placas foram incubadas durante 24/48 horas (podendo estender-se a uma semana) a $30^{\circ} \mathrm{C}$ para as bactérias e $20^{\circ} \mathrm{C}$ para os fungos. Após a contagem das colônias, as placas foram usadas para posterior isolamento de culturas microbianas. Foram realizadas contagens de bactérias e fungos filamentosos em meios específicos: Celulolíticos (CMC), Proteolíticos (Agar Gelatina) e Solubilizadores de Fosfato (Sais de Fosfato). Os microrganismos com atividade celulolítica foram evidenciados através do crescimento no meio sólido Dubos (meio contendo apenas sais minerais essenciais e carboximetilcelulose) como única fonte de carbono, e quantificados segundo LINHARES E DROZDOWICZ (1972). Os microrganismos proteolíticos, com potencial para crescer no meio mineral enriquecido apenas com gelatina, foram detectados por meio da formação de halo ao redor das colônias proteolíticas. Nessa técnica, o corante "Coomasie Blue" é utilizado para evidenciar a degradação da proteína. Um volume do corante foi vertido dentro da placa até cobrir toda a superfície do meio, por um tempo de 5-10 minutos; posteriormente, a placa foi lavada com uma solução de ácido acético 
$(50 \%)$ com metanol $(50 \%)$ para retirar o excesso e a parte do corante que não se impregnou a proteína, que é então eliminada. (LADD e BUTLER, 1972). Os microrganismos capazes de solubilizar fosfato foram quantificados através de um halo transparente ao redor das colônias cultivadas em meio de cultura, constituído de sais minerais com glicose e sais de fosfatos insolúveis (HOFFMAN, 1967).

\section{Isolamento e caracterização de bactérias}

Foram selecionadas, das placas de cultivo, colônias bacterianas representativas das diferentes morfologias. Estas foram submetidas ao isolamento em cultura pura nos respectivos meios de contagem. A cultura foi caracterizada usando os seguintes testes fenotípicos: morfologia celular, coloração de Gram, oxidação/ fermentação, motilidade, citrato, catalase, nitrato, urease e fermentação de carboidratos (maltose, dextrose, xilose, sacarose, glicose, manitol e lactose). As culturas foram identificadas ao nível de gênero de acordo as descrições citadas no Bergey's Manual (1994) e MacFaddin (1976).

\section{Extração de DNA das culturas bacterianas}

A extração de DNA das culturas bacterianas foi realizada após os testes bioquímicos, em que foram escolhidas estirpes representativas dos gêneros pertencentes ao grupo bacilo Gram positivo, totalizando 41 estirpes da parcela FP e 37 da FS, respectivamente. Este método foi efetuado usando o protocolo de HURT et al. (2001), utilizando agitação com pérolas de vidro em Fast Prep (Fast Prep TM FP 120; Bio101 Thermo Electron Corp. $\left.{ }^{\circledR}\right)$ a uma velocidade 5,5 por 20 segundos. Em seguida, a lise das células foi realizada embanho-maria $65^{\circ} \mathrm{C}$ por 30 minutos e centrifugação 10000 g, 5 minutos. A preparação foi extraída com Clorofórmio Álcool isoamílico (24:1) e o DNA, precipitado com isopropanol $(80 \%)$ gelado e diluído em tampão Tris-Edta (TE). A pureza e peso molecular das preparações de DNA foram testados em gel de agarose $(0,8 \%)$ corado com Brometo de Etídio e observado sob luz UV (254 nm). Foi usado como padrão um marcador com $1 \mathrm{~Kb}$ de peso molecular
(SAMBROOK et al., 1989).

\section{Caracterização Genotípica - BOX-PCR}

A caracterização genotípica das culturas bacterianas foi através da técnica BOX-PCR (RADEMAKER et al., 1998). A reação para amplificação foi feita utilizando Go Taq master Mix (PROMEGA), de acordo com as recomendações do fabricante. Foi usado o Primer: BOXA1R (5'-CTA CGG CAAGGC GAC GCT GAC TGA CG-3') (VERSALOVIC et al., 1994), e o programa de amplificação foi: Desnaturação a $94^{\circ} \mathrm{C}$ por 7 minutos; Ciclos $94^{\circ} \mathrm{C}$ por 1 minuto.; $53^{\circ} \mathrm{C}$ por 1 minuto e $65^{\circ} \mathrm{C}$ por 1 minuto $(35 \mathrm{X})$ e Extensão final, $65^{\circ} \mathrm{C} 16$ minutos (Termociclador Gene Amp® PCR System 9700; Applied Biosystems). O produto do PCR foi visualizado através de eletroforese em gel de Agarose (Invitrogen) a 100Volts por 4 horas; observados em um transiluminador UV (254nm) após a coloração com Brometo de Etídeo (SAMBOOK et al., 1989). Os perfis de BOX-PCR foram analisados por meio do programa estatístico BioDiversity Professional Beta (MACALEECE, 1998), com o coeficiente de similaridade de Jaccard e o algoritmo de agrupamento UPGMA.

\section{Resultados e Discussão \\ Análises Físico-Químicas}

A Tabela 1 apresenta as características físicoquímicas e de textura das amostras de solo. Os resultados indicaram similaridade física entre as amostras e um nível de acidez elevada, característica dos solos da Floresta Amazônica (NAHAS, 1994). As concentrações dos nutrientes pesquisados também foram próximas nas duas amostras. A diferença do percentual de matéria orgânica não foi expressiva na parcela submetida a estresse hídrico (FS), em comparação com a parcela controle (FP). De acordo com Ferreira et al. (2006), a pobreza do solo da floresta decorre do fluxo de saída ou perdas nutricional do sistema por meio do processo de lixiviação e também porque boa parte dos nutrientes que entram na floresta são retidos pela mesma. 
Tabela 1 - Propriedades físico-químicas das amostras de solo.

\begin{tabular}{|c|c|c|c|c|c|c|c|c|}
\hline Amostra & $\begin{array}{c}\text { Textura } \\
\text { (Expedita) }\end{array}$ & $\mathrm{pH}$ & $\begin{array}{l}\mathrm{Al} \\
{ }^{*} \mathrm{Cr}\end{array}$ & $\begin{array}{l}\mathrm{Ca}+\mathrm{Mg} \\
/ \mathrm{dm}^{3}\end{array}$ & $P_{* *}$ & $\begin{array}{c}\mathrm{K} \\
\mathrm{g} / \mathrm{dm}^{3}\end{array}$ & $\mathrm{C}$ & $\begin{array}{l}\text { M.O } \\
\%\end{array}$ \\
\hline Floresta Primária & argilosa & 4,0 & 2,0 & 0,6 & 5,0 & 15,0 & 2,23 & 3,85 \\
\hline Floresta Seca & argilosa & 4,1 & 1,8 & 0,7 & 4,0 & 15,0 & 2,04 & 3,52 \\
\hline
\end{tabular}

${ }^{*} \mathrm{~cm}_{\mathrm{c}} / \mathrm{dm}^{3}$ concentração de alumínio por diâmetros cúbicos; $* * \mathrm{mg}^{*} / \mathrm{dm}^{3}:$ concentração de bases por diâmetros cubicos; **** \%: Percentagem de Matéria Orgânica

\section{Análises microbiológicas do solo}

A Figura 1a apresenta os valores obtidos para as populações de bactérias nas amostras de solo coletadas em Junho de 2005 e em Janeiro de 2006, cultivadas em TSA e meios específicos. Foram observadas variações nas contagens bacterianas tendendo à redução na parcela FS. Em coletas anteriores (dados não apresentados) houve uma redução, de cerca de duas ordens de grandeza, no número de bactérias na FS. A redução foi mais significativa na população de bactérias capazes de degradar celulose, sob estresse hídrico, nas coletas de Junho de 2005 e Janeiro de 2006. A pouca atuação das bactérias celulolíticas talvez seja explicada devido à ausência de precipitação, sem a qual não ocorre o carreamento dos nutrientes disponíveis na parte decomposta da serrapilheira, ou porque os microrganismos oriundos das camadas mais superficiais do solo não consigam alcançá-la. Moutinho (2002) reportou nesse sistema (projeto "Dry Forest") uma diminuição da área foliar que interfere na ciclagem de nutrientes para o solo. Esses dados corroboram com os de Smitt et al. (2001), sugerindo que esse fato pode ser devido à diferença na fisiologia celular de alguns microrganismos em resposta ao estresse hídrico. Certas espécies bacterianas isoladas de solos com déficit de água podem sofrer um choque quando são re-hidratadas. A interpretação desses resultados também deve levar em conta as limitações do método de contagem em placas, o qual seleciona as espécies que formam colônias e se desenvolvem bem no meio de cultura utilizado, e também porque algumas estirpes podem estar em estado não cultivável no ambiente ficando excluídas da análise (ZILLI et al., 2003; CARNEIRO et al., 2004).

A Figura $1 \mathrm{~b}$ representa as contagens de fungos. Esta população apresentou menor sensibilidade ao estresse hídrico, tendo mantido contagens próximas em todos os meios utilizados e diferença pouco significativa na comparação entre as amostras de parcela FS e FP, exceção das amostras coletadas em 2006 com redução de duas ordens de magnitude na contagem de fungos da parcela FS. Segundo os autores Kempf e Bremer (1998) e Schimel (1999), os fungos são mais resistentes ao estresse, em razão da rigidez da parede celular. A quantificação fúngica também possui suas limitações, como o rápido crescimento celular e a proliferação de filamentos que dificultam a contagem de colônias. 


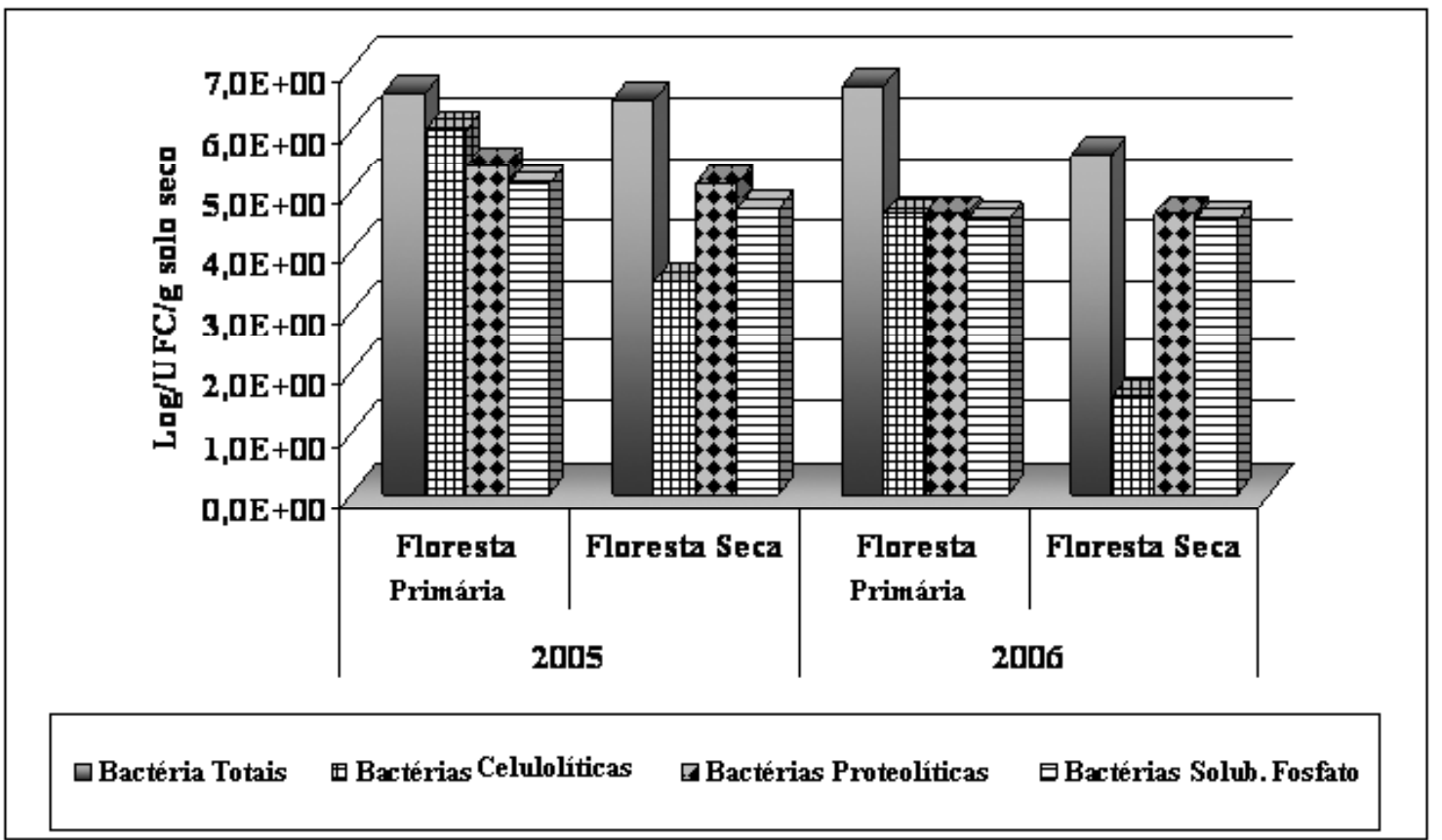

Figura 1a - Contagens de bactérias em amostras de solo de Floresta Primária e Floresta Seca, Projeto"Dry Forest", Floresta Nacional de Tapajós. Os dados correspondem às médias geométricas e desvio padrão das contagens em logaritmo das unidades formadoras de colônias (UFC) cultivadas em TSA, CMC, Agar Gelatina e Sais de Fosfato. Amostras coletadas em Junho de 2005 e Janeiro de 2006.

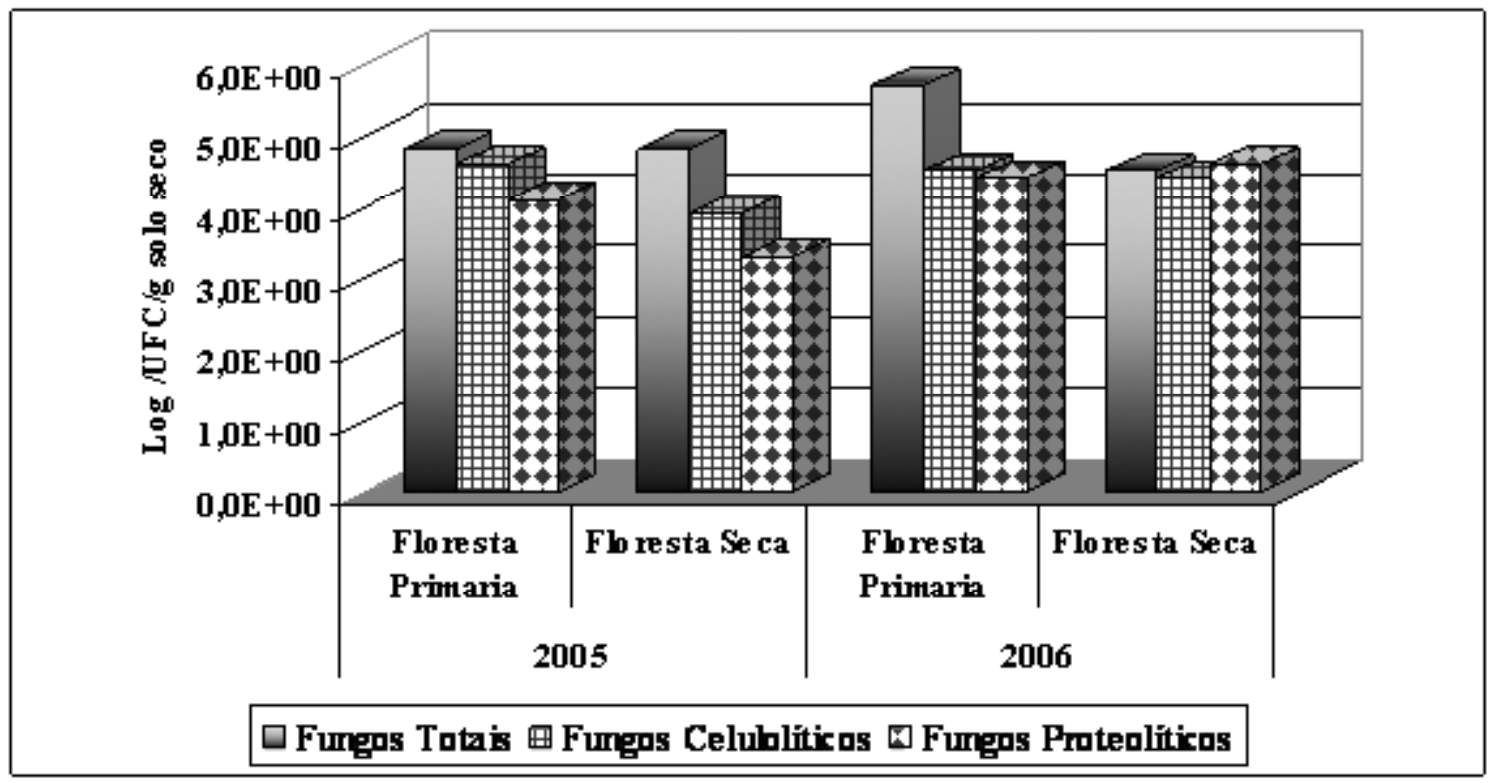

Figura 1b - Contagens de fungos em amostras de solo de Floresta Primária e Floresta Seca, Projeto"Dry Forest", Floresta Nacional dos Tapajós. Os dados correspondem às médias geométricas e desvio padrão das contagens em logaritmo das unidades formadoras de colônias (UFC) cultivadas em PDA, CMC, Agar Gelatina e Sais de Fosfato. Amostras coletadas em Junho de 2005 e Janeiro de 2006. 


\section{Diversidade de bactérias isoladas de amostras de solo}

Foram isoladas 286 estirpes bacterianas dos solos das parcelas, oriundos das duas coletas, sendo 153 isoladas da FP e 133 da FS a partir dos meios de cultivo. A caracterização morfológica das culturas bacterianas foi efetuada através da coloração de Gram. Considerando suas características morfotintoriais, as estirpes foram divididas em grupos, sendo a maioria formada de bacilos Gram positivos, seguidos de cocos Gram positivos (Figura 2). A prevalência dos bastonetes Gram positivos pode estar relacionada ao fato de que a maioria das bactérias pertencentes a esse grupo formam esporos ou estágios fisiológicos com baixa atividade metabólica mediante uma situação adversa, como a escassez de água.

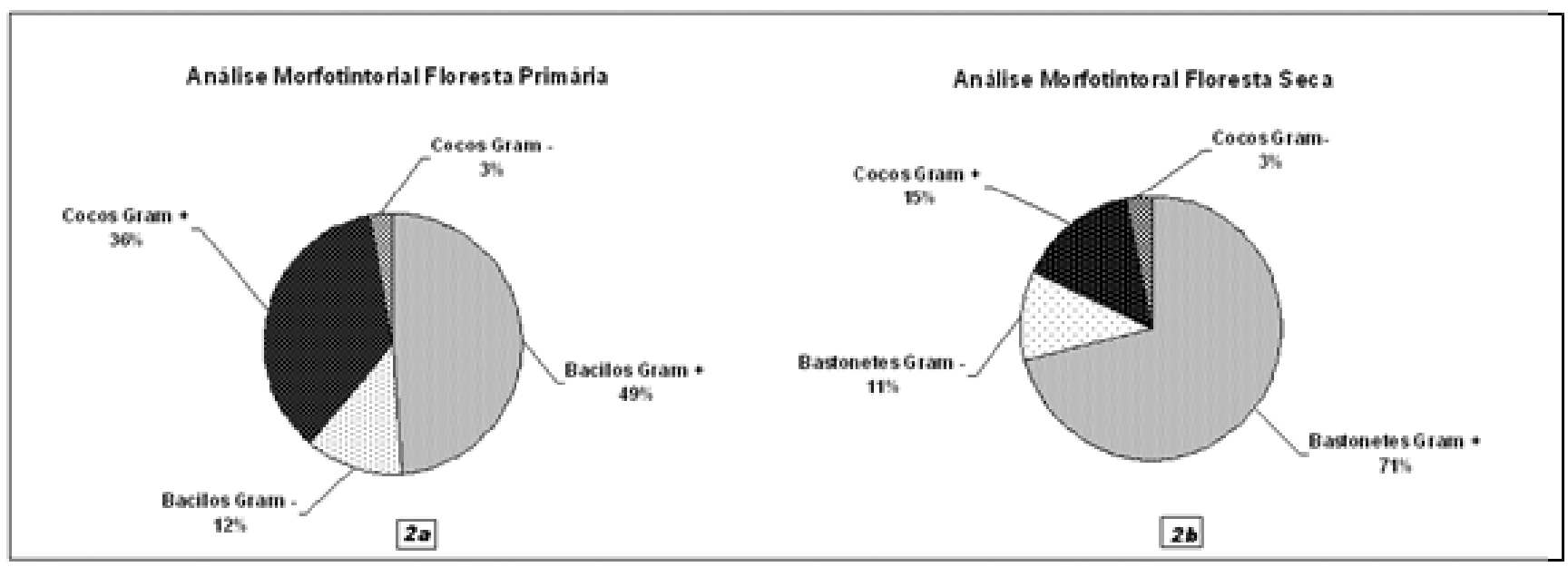

Figura 2 - Caracterização morfológica e tintorial (Gram) das culturas isoladas de solos de Floresta Primária (FP) e Floresta Seca (FS).

A identificação dos gêneros das estirpes isoladas foi feita de acordo com os testes morfológicos e fisiológicos, seguindo as chaves de identificação do Bergey's Manual (1994) e MacFaddin (1976). O resultado dos testes bioquímicos confirma que a maioria dos isolados pertence ao grupo bacilos Gram positivos, considerando que a maioria dos gêneros identificados pertence a esse grupo. Esse dado corrobora com outros resultados citados na literatura, onde é relatado que este grupo é um grande representante da comunidade bacteriana do solo. A presença de cocos Gram positivos também foi expressiva, como Streptococcus e Staphylococcus, gêneros normalmente associados aos animais de sangue quente. Este resultado pode ser explicado considerando que o solo não é um ambiente isolado, possuindo ligações diretas com as águas, ar, plantas e animais. Na Tabela 2 estão representados os gêneros prevalentes isolados nos solos estudados. Os gêneros encontrados com menor frequência foram: Acinetobacter, Cromobacterium, Flavobacterium, Enterobacter. 
Tabela 2 - Gêneros bacterianos prevalentes isolados das amostras de solo da Floresta Nacional do Tapajós - Projeto "Dry Forest".

\begin{tabular}{|c|c|c|c|c|c|}
\hline \multicolumn{2}{|c|}{ Gram Positivo } & \multicolumn{2}{|c|}{ Gram Negativo } & \multirow{2}{*}{\begin{tabular}{|l} 
Floresta \\
Primária
\end{tabular}} & \multirow{2}{*}{$\begin{array}{c}\text { Floresta } \\
\text { Seca }\end{array}$} \\
\hline Bastonetes & $\operatorname{Cocos}$ & Bastonetes & Cocos & & \\
\hline \multirow{2}{*}{ Actinomyces } & & & & 6 & 8 \\
\hline & & & Aeromonas & 1 & 7 \\
\hline Alcaligenes & & & & 8 & 4 \\
\hline Artrobacter & & & & 5 & 7 \\
\hline Bacillus & & & & 17 & 18 \\
\hline Corynebacterium & & & & 19 & 18 \\
\hline Eubacterium & & & & 2 & 5 \\
\hline Lactobaccilus & & & & 3 & 4 \\
\hline \multirow[t]{5}{*}{ Listeria } & & & & 14 & 30 \\
\hline & Micrococcus & & & 15 & 13 \\
\hline & & Pseudomonas & & 6 & 16 \\
\hline & Staphylococcus & & & 15 & 6 \\
\hline & Streptococcus & & & 18 & 11 \\
\hline \multicolumn{4}{|c|}{ Outros isolados nẵo identificados } & & 2 \\
\hline \multicolumn{4}{|c|}{ Isolados identificados } & 129 & 149 \\
\hline \multicolumn{4}{|c|}{ Total } & 129 & 151 \\
\hline
\end{tabular}

\section{BOX-PCR dos Isolados Bacterianos}

As bactérias possuem sequências naturais, altamente conservadas e repetitivas no DNA, as quais estão presentes em várias cópias no genoma. Essas sequências parecem estar localizadas em posições intergênicas distintas ao redor do cromossomo; o elemento BOX foi identificado por possuir essas sequências (DIMRI et al., 1992). A Figura 3 apresenta o perfil genético de 41 estirpes isoladas da área FP, onde foi observada uma alta diversidade. Resultado semelhante foi encontrado na análise das 37 isoladas da parcela FS (Figura 4). Os perfis genotípicos obtidos através da técnica de BOX-PCR estão apresentados por meio dos dendrogramas. A matriz de similaridade foi gerada usando o índice de Jaccard, em que as medidas de semelhança são grandezas numéricas que quantificam o grau de associação entre os isolados. As estirpes oriundas de solos FP e FS apresentaram perfis genotípicos com baixo grau de similaridade ao nível de resolução de espécie/subespécie, indicando alta diversidade, embora estas culturas pertençam a poucos gêneros bacterianos. Segundo Rademaker et al. (2005), o uso da técnica do BOX-PCR permite fazer diferenciação de subespécies através do uso de DNA de isolados; porém, esse método gera perfis 
complexos. Esse fato foi verificado nos perfis de BOX-PCR encontrados no presente estudo para as bactérias de solo de floresta. A técnica engloba a análise do genoma como um todo, assim sendo, a probabilidade para duas estirpes distintas revelarem o mesmo perfil em BOX-PCR é virtualmente nula, devido ao fino grau de resolução genética da análise, conforme relatou Costa (2001; COSTA et al., 2006) para a caracterização genotípica de bactérias pertencentes ao gênero Pseudomonas.

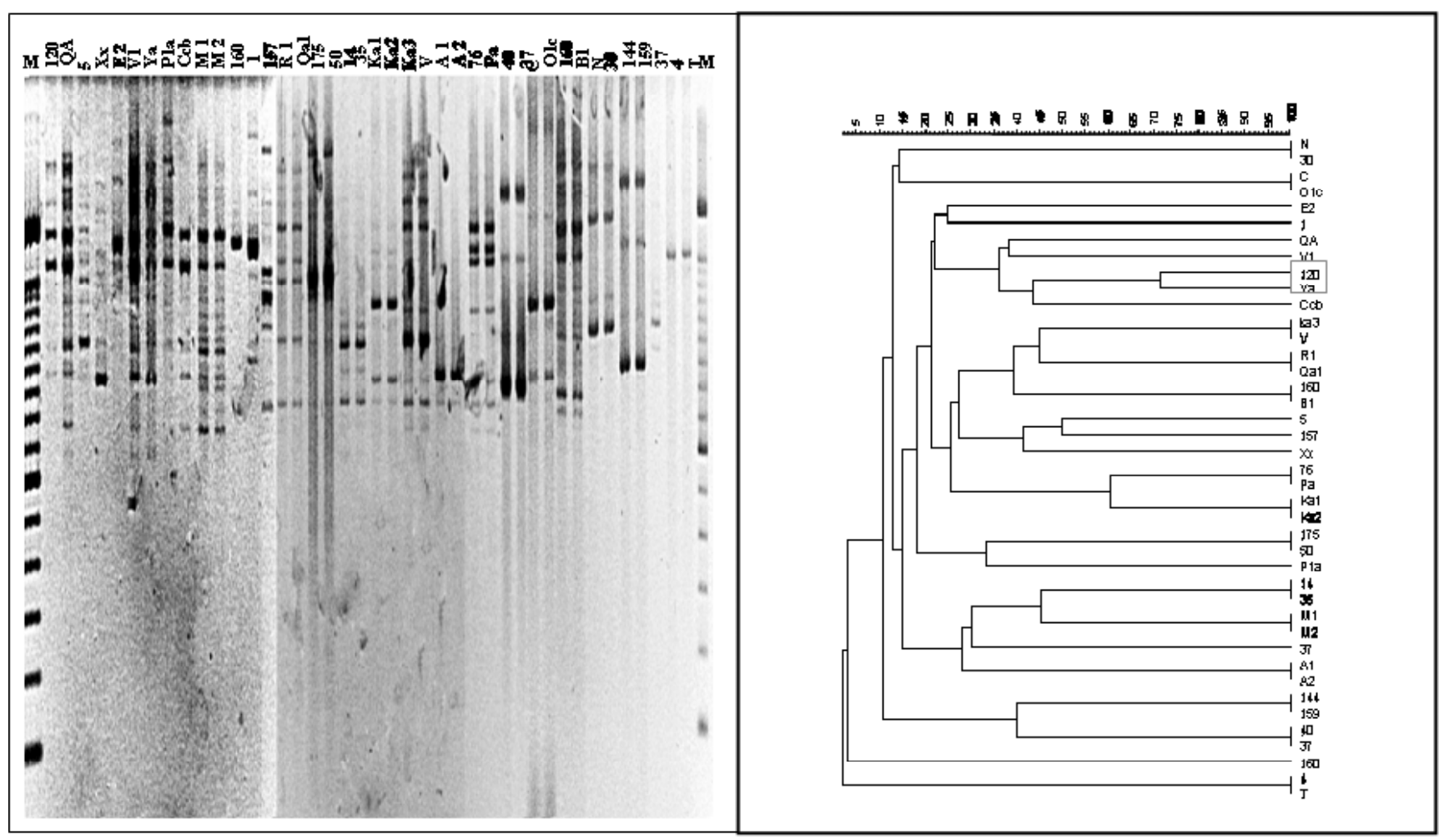

Figura 3 - Caracterização genotípica via BOX-PCR de Bacilos Gram positivos isolados da parcela Floresta Primária. M: marcador de peso molecular (100pb). Estirpes bacterianas: indicadas pelos códigos e agrupamento (UPGMA de acordo com os perfis genotípicos determinados por BOX-PCR. O percentual de similaridade entre os isolados da amostra Floresta Primária foi obtido a partir de uma matriz construída através da análise de Jaccard. 


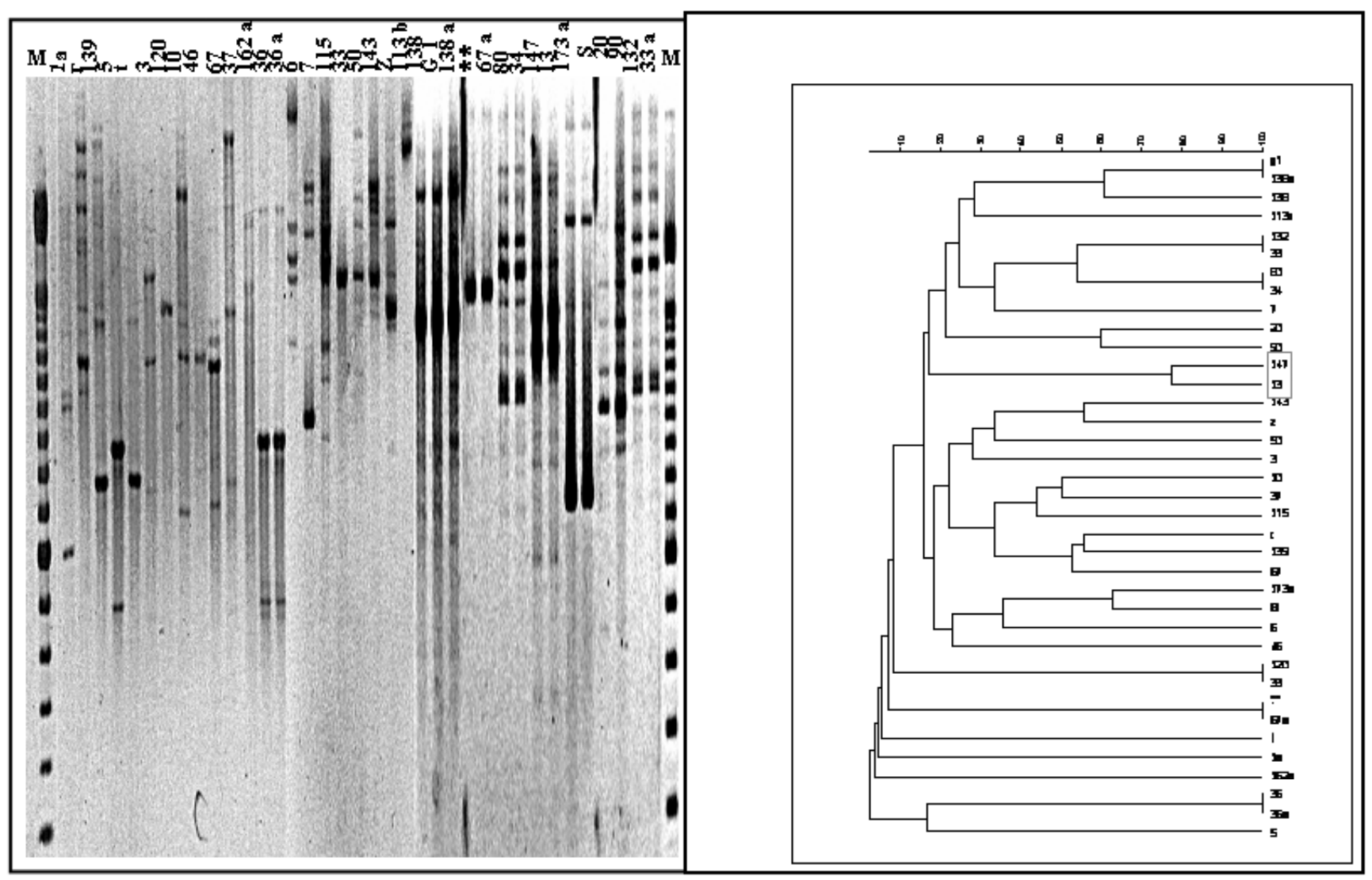

Figura 4 - Caracterização genotípica via BOX-PCR de Bacilos Gram positivos isolados da parcela Floresta Seca. M: marcador de peso molecular (100pb). Estirpes bacterianas: indicadas pelos códigose agrupamento (UPGMA) de acordo com os perfis genotípicos determinados por BOX-PCR. O percentual de similaridade entre os isolados da amostra Floresta Seca foi obtido a partir de uma matriz construída através da análise de Jaccard.

Os resultados obtidos no presente estudo sugerem que a queda nas populações microbianas e a redução nos valores das atividades enzimáticas podem ser decorrentes da escassez de água, pois esta é a variável mais expressiva que diferencia as parcelas Floresta Primária e Floresta Seca. A diversidade microbiana não foi significativamente afetada ao nível de gêneros bacterianos encontrados nos solos analisados, estes representados predominantemente por bastonetes Gram positivos. Acaracterização genética de estirpes representativas gerou perfis complexos de similaridade entre os genótipos bacterianos, sinalizando elevada diversidade de espécies e genótipos presentes nas comunidades microbianas do solo da Floresta dos
Tapajós, fato que pode explicar a reconhecida resiliência do solo (GIRVAN et al., 2005) frente aos períodos de secas neste ecossistema.

\section{Agradecimentos}

Agradecemos à equipe do projeto "Dry Forest" e Ao Ibama-Pará pela concessão das amostras, bem como à Embrapa pelas análises dos solos. O presente estudo recebeu apoio financeiro das agências Capes, CNPq e Faperj.

\section{REFERÊNCIAS}

ALEF, K., KLEINER, D., Arginine ammonification 
in soil samples In: Methods in Applied Soil Microbiology and Biochemistry. 3. ed. London: Academic Press, 1986. v.18, p.163-168.

ARIAS, M. E., GONZÁLEZ-PÉREZ, J. A., GONZÁLEZ-VILA, F. J., BALL, A. S., Soil healta new challenge for microbiolists and chemists.

International Microbiology. v.8, p.13- 21, 2005.

BAHL O. P., AGRAWAL, K. M. L., ?-

Galactosidades, $\beta$-glucosidade, and $\beta-\mathrm{N}$ acetylglucosaminidase from Aspergillus niger. In: Methods in Enzimology, Academic Press, New York, v. 28. p. 728- 734, 1972.

BRADY, N. C., Colóides do Solo: Sua natureza e significação prática. In: . Natureza e

Propriedade do Solo, Rio de Janeiro: Freitas Bastos, 1989. p. 161-212.

BORNEMAN, J., TRIPLETI, E. W., Molecular microbial diversity in soil from Eastern Amazonia: evidence for unusual microorganisms and microbial population shifts associated with deforestation.

Applied and Environmental Microbiology. v. 63, n. 7, p. 2647-2653, 1997.

CARNEIRO, R. G., MENDES, I. C., LOVATO, P. E., CARVALHO, A. M., VIVALDI, L. J., Indicadores biológicos associados ao ciclo do fósforo em solos de Cerrado sob plantio direto e plantio convencional. Pesquisa Agropecuária Brasileira. v. 39, n.7, p.661-669, 2004.

CERRI, C. C., VOLKOFF, B., EDUARDO, B. P. Efeito do desmatamento sobre a biomassa microbiana em latossolo amarelo da Amazônia. Revista Brasileira de Ciência do Solo. v. 9, n.1, p.1-4, 1985.

CUNHA, U. S., MACHADO, S. A., E FILHO, A. F. Uso de análise exploratória de dados e de regressão robusta na avaliação do crescimento de espécies comerciais de terra firme da Amazônia. Revista Árvore Sociedade de Investigações Florestais (SIF). v. 26, n.4, p. 391-402, 2002.

COSTA, R. S. Variabilidade e diversidade genética de comunidades bacterianas associadas a rizosfera de milho (Zea mays $L$. Merril) em um agrossistema do Rio de Janeiro, p.127. Dissertação (Mestrado) - Universidade Federal do Rio de Janeiro, Rio de Janeiro, 2001.

COSTA, R. S., GOMES, N. C. M., PEIXOTO, R. S, RUMJANEK, N., BERG, G., MENDONÇAHAGLER, L. C. S., SMALLA, K., Diversity and antagonistic potential of Pseudomonas spp. associated to the rhizosphere of maize grown in a subtropical organic farm. Soil Biology and Biochemistry. v. 38, p. 2434-2447, 2006.

DE BRUIJN, F. J., RADEMAKERS, J., SCHENEIDER, M., ROSSBACH, U., DIMRI, G. P., RUDD, K. E., MORGAN, M. K.; BAYATT, H., AMES, G. F. L. Physical mapping of repetitive extragenic palindromic sequences in Eschrichia coli strains and others enteric bacteria. Journal of Bacteriology. v. 174, p. 4583-4593, 1992.

DIMRI, G. P.; RUDD, K. E. MORGAN, M. K.; BAYATT, H.; AMES, G. F. L. Physical mapping of repetititive extragenic palindromic sequences in Eschrichia coli strains and others enteribacteria. Journal of bacteriology.v. 174, p. 4583-4593, 1992.

EMBRAPA. Manual de métodos de análises químicas para avaliação da fertilidade do solo. Rio de Janeiro, 1998. p.78.

FERREIRA, S. J.F., LUIZÃO, F. J., MIRANDA, S. A. F., SILVA, M. S. R. VITAL, A. R. T. Nutrientes na solução do solo em flores de terra firme na Amazônia central submetidaà extração de madeira. Acta Amazônica. v.36, n.1, p.59-68, 2006. 
GIRVAN, M. S., CAMPBELL, C. D., KILLHAM, K., PROSSER, J. L., GLOVER L. A. Bacterial diversity promotes community stability and functional resilience after perturbation. Environmental

Microbiology. v.7, n.3, p.301-313, 2005.

\section{HOFFMAN, G. Eine photometrische Methode} zur Bestimmung der Phosphatase-Aktivität in Böden. Z Pflanzernernaehr Bodenkd, 1967. n.118, p. 161-172.

HURT, R. A. QIU, X., WU, L. ROH, Y. PAUMBO, A. V. TIEDJE, J. M. ZHOU, J., Simultaneous recovery of RNA and DNA from soil and sediments. Applied and Environmental Microbiology. v. 67, n. 10, p. 4495-4503, 2001.

KALIF, K. A. B., AZEVEDO-RAMOS, C. NUNES, A. S. Conhecendo a Amazônia. Projeto Soma Universidade Federal do Pará e Instituto de Pesquisa Ambiental da Amazônia (UFPA/IPAM), 2000. p. 29.

KEMPF, B., BREMER E., Uptake and synthesis of compatible solutes as microbial stress responses to high osmolality environments. Arch Microbiology. n.170, p.319-330, 1998.

KISS, S., DRAGAN-BULARDA, M., RADULESCU, D., Biological significance of enzymes in soil. Advances. agronomic. n. 27, p. 25-91, 1975.

LADD, J.N., BUTLER J.H.A., Short-term assays of soil proteolytic enzyme activities using proteins and dipeptide derivates as substrates. Soil Biological Biochemical. n. 4, p.19-30, 1972.

LADD, J.N., Origin and range of enzymes in soil. In:__ Soil Enzymes. 3. ed. London, Academic Press, 1978. v.1, 6, p.51-96.

LINHARES, L.F., DROZDOWICKZ, A.,
Atividade Celulolitíca em alguns solos brasileiros. Revista de Microbiologia. v. 3, n. 2, p. 91-100, 1972.

MCALEECE N., LAMBSHEAD P.J.D., PATERSON G.L.J.; CAGE J. D., Biodiversity Natural History Museum and Scottish Association for Marine Science. 1998. Disponível em: http://www.sams.ac.uk/dml/projects/ benthic/bdpro. Acesso em Nov. 2005.

MACFADDIN, J. F. Biochemical testes for identification of medical bacteria. 2. ed. Baltimore: Williams e Wilkins, 1976. p. 527.

MOUTINHO, P., Efeito da seca prolongada na Amazônia: quando a floresta torna-se inflamável? Relatório técnico detalhado. v. 1173, n. 99, 2002.

MORRA, M. J., FREEBORN, L.L., Temperature effects on soil urease activity. Soil Biological Biochemical. n. 21, p. 935-938, 1989.

MUZILLI, O. Análise de solos: Interpretação e recomendação de calagem e adubação. Londrina: LAPAR. p. 48, 1978.

NAHAS, E., CENTURION, J. F., ASSIS, L. C., Microrganismos solubilizadores de fosfato e produtores de fosfatases de vários solos. Revista Brasileira de Ciências do Solo. n.18, p.43-48, 1994.

NAHAS, E., Microrganismos do solo produtores de fosfatases em diferentes sistemas agrícolas. Revista brasileira de Ciências do Solo. n. 61, v. 3, p. 267-275, 2002.

NEPSTAD, D. C., JIPP, P., MOUTINHO, P., NEGREIROS, G., E VIEIRA, S., Forest recovery following pasture abandonment in Amazonia: canopy seasonality, fire resistence and ants. NATO ASI evaluating and Monitoring the Health of Larga- 
Scale Ecosystems. n .128, p. 333-349, 1995.

NEPSTAD, D. C., The effects of partial throughfall exclusion on canopy processes, aboveground production and biogeochemistry of an amazon forest. Journal Geophysical Research. n. 107, v. 53, p. 1-18, 2000.

PAUL, E. A., CLARK, F. E. Soil microbiology and biochemistry. Soil Biology and Biochemistry. v. 29, p. 1433-1441, 1996.

RAI, B., SRIVASTAVA, A. K. Decomposition and competitive colonization of leaf litter by fungi. Soil Biology and Biochemistry. v . 15, p. 115-117, 1983.

RADEMAKER, J. L. W., LOUWS, F. J., DE BRUIJN, F. J., Characterization of the diversity of ecologically important microbes by Rep-PCR genomic fingerprint. Molecular. Microbiology Ecology. n. 34, v. 3, p. 1-27, 1998.

RADEMAKER, J. L. W., ARTS, H. J. M., VINUESA, $P$. Molecular typing of environmental isolates: Molecular Microbial ecology. Osborn: M. Smith, 2005. p. 97-134.

SAMBROOK, J., FRITSCH, E. F., MANIATIS, T. Molecular cloning: a Laboratory Manual. 5th. ed. New. York: Cold Spring Harbor Laboratory Press, Cold Spring Harbor, 1989, p.578.
SCHIMEL, J. P., GULLEDGE, J. M., CLEINCURLEY, J. S., LINDSTROM, J. E., BRADDOCK, J. F., Moisture effects on microbial activity and community structure in decomposing birch liter in the Alaskan taiga. Soil Biological Biochemical. v. 31, p. 831-838, 1999.

SMITT, E. LEEFLANG, P., GOMMANS, S., BROEK, J., MIL, S., WERNARS, K., Diversity and seasonal fluctuations of the dominant members of the bacterial soil community in a wheat field as determined by cultivation and molecular methods. Applied and Environmental Microbiology. v. 5, n. 67, p. 2284-2291, 2001.

SINSABAUGH, R.L., LINKINS, A. E., Adsorption of cellulose components by leaf litter. Soil biology and biochemistry. v. 20, p. 927-931, 1988.

TABATABAI, M.A., Enzymes. In: Weaver, R.W., Augle, S, Bottomly, P.J., Berdicek, Q., Smith, S., Tabatabai, A., Wollum, A. Methods of Soil Analysis Microbiological. 3rd ed. London: Academic Press, 1994, v.18, p. 163-168.

ZILLI, J. E., RUMJANEK, N. G. XAVIER, G. R., COUTINHO, H. L. C., NEVES, M. C. P., Diversidade microbiana como indicador de qualidade do solo. Cadernos de Ciências e Tecnologia. n. 20, v. 3, p. 391-411, 2003. 